\title{
PELATIHAN KEWIRAUSAHAAN STRATEGI ONLINE MARKETING UNTUK MEMPERLUAS PASAR
}

\author{
Afif Hakim ${ }^{1}$, Nana Rahdiana ${ }^{2}$, Annisa Indah $\mathbf{P}^{3}$ \\ ${ }^{1,2,3}$ Teknik Industri, Fakultas Teknik dan Ilmu Komputer \\ Universitas Buana Perjuangan Karawang \\ afif.hakim@ubpkarawang.ac.id ${ }^{1}$ \\ nana.rahdiana@ubpkarawang.ac.id ${ }^{2}$ \\ annisa.indah@ubpkarawang.ac.id ${ }^{3}$
}

\begin{abstract}
Abstrak
Sebagai seorang entrepreneur harus selalu berupaya mencari ide kreatif agar usaha yang dijalankan dapat terus berjalan. Salah satu improvement yang dapat dilakukan adalah mengubah strategi pemasaran dari konvensional (offline) menjadi online atau yang sering disebut online/internet marketing terlebih lagi pada saat kondisi pandemic Covid-19 seperti saat ini. Untuk menjalankan online marketing memang tidak mudah dan butuh ketelatenan. Banyak para peserta yang beranggapan bahwa strategi online marketing sulit untuk dilaksanakan pada hal mereka menyadari bahwa strategi online marketing efektif untuk dilaksanakan terutama di saat-saat pandemic covid-19 ini sehingga pelatihan semacam ini penting untuk dilaksanakan untuk menghilangkan gap berupa ketidaktahuan para peserta. Pelatihan berjalan dengan lancar dan para peserta terlihat antusias dalam melaksanakan pelatihan ini terbukti dari banyaknya pertanyaan yang dilontarkan dan hasil survey feedback menyatakan bahwa $100 \%$ mereka setuju pelatihan membawa manfaat untuk pengembangan usaha.
\end{abstract}

Kata kunci-entrepreneur, Covid-19, online marketing

\begin{abstract}
As the entrepreneur, they must always try to find creative ideas so that his business can continue to run. One of the improvements that can be made is to change the strategy from conventional (offline) marketing to online or what is often called online / internet marketing first during the Covid-19 pandemic conditions like today. To run online marketing is not easy and requires patience. Many participants thought that online marketing strategies were difficult to implement when they realized that an effective online marketing strategy was to be implemented, especially during this time of the Covid-19 pandemic, so this kind of training is important to carry out to eliminate the gap in the form of participants' ignorance. The training went well and the participants seemed enthusiastic in carrying out the training as evidenced by the many questions asked and the survey results which stated that $100 \%$ of them agreed that the training was beneficial for business development.
\end{abstract}


Keywords-entrepreneur, Covid-19, online marketing

\section{PENDAHULUAN}

Pengabdian kepada masyarakat merupakan salah satu tri dharma yang wajib dilaksanakan oleh para dosen dalam setiap tahunnya sebagaimana tertuang pada UndangUndang RI Nomor 12 Tahun 2012 tentang Pendidikan Tinggi. Pada awal tahun 2020, Indonesia dilanda musibah yakni dengan adanya wabah virus corona yang dapat menyebabkan penyakin Corona Virus Disease 2019 (COVID-19). Hal ini membuat pemerintah memutuskan Status Darurat Kesehatan Masyarakat dan menetapkan kebijakan Pembatasan Sosial Berskala Besar (PSBB) di beberapa daerah. PSBB membatasi aktivitas masyarakat untuk tidak berkerumun, menerapkan psyical distancing dan harus tinggal di rumah guna memutus mata rantai penyebaran COVID- 19 tersebut. Penetapan tersebut nyaris merubah hampir semua aktivitas keseharian warga dan sendi-sendi kehidupan manusia. Akibat adanya pembatasan tersebut, perekonomian nyaris lumpuh dan terpuruk. Menurut sumber BPS,Ekonomi Indonesia triwulan II-2020 terhadap triwulan II-2019 mengalami penurunan pertumbuhan sebesar 5,32 persen. Hal ini tentu sangat berdampak bagi seluruh sektor industri dari mulai industry besar sampai dengan industri kecil dan UMKM.

Bagi para pelaku usaha dengan adanya wabah tersebut, harus dapat memutar otak, mencari strategi baru agar bisnisnya dapat berjalan di tengah situasi yang sangat sulit. Diantara terobosan yang sangat diperlukan adalah dengan cara memindahkan toko dari toko ofline ke dalam toko dalam dunia maya (online). Bagi yang sudah terbiasa dengan berjualan online, hal tersebut merupakan hal yang biasa saja. Berbeda dengan pelaku usaha yang biasanya hanya membuka toko offline, tentu hal tersebut dirasa sulit dan merupakan tantangan tersendiri. Oleh karena itu, dalam kegiatan pengabdian kepada masyarakat ini, dilakukan pelatihan mengenai bagaimana membangun strategi online marketing untuk mengedukasi dan membantu para pelaku usaha terutama usaha mikro dan UMKM agar tetap eksis berjualan dan dapat bersaing di masa pandemi covid-19 ini.

Menurut Dianawati (2007) Pemasaran online adalah kegiatan komunikasi pemasaran dengan menggunakan media internet. Sedangkan menurut David dan George (2001) marketing online adalah penggunaan network untuk meraih pelanggan. Berdasarkan media cetak kompas (2020) aktivitas belanja online meningkat selama masa pandemic ini. Sehingga hal tersebut justru merupakan kesempatan dan pasar yang baru yang harus dikejar. Adapun tujuan dari kegiatan ini adalah: 
1. Mendorong mahasiswa dan juga masyarakat umum untuk dapat memulai berjualan secara online

2. Mendorong para pelaku usaha terutama usaha mikro dan UMKN untuk dapat beradaptasi memulai menjalankan strategi online marketing agar bisnis yang dijalankan dapat tetap eksis di masa pandemi covid-19

Dari uraian di atas, permasalahan yang diangkat dalam kegiatan pengabdian pada masyarakat ini pada intinya adalah bagaimana memberikan edukasi dan pelatihan kepada para mahasiswa dan masyarakat luas pelaku usaha untuk memulai berwirausaha dan beradaptasi dengan melaksanakan strategi online marketing.

Tabel 1. Matrik upaya untuk pemecahan masalah

\begin{tabular}{|c|c|}
\hline Perumusan masalah & Upaya pemecahan masalah \\
\hline $\begin{array}{l}\text { Bagaimana meningkatkan motivasi } \\
\text { dan semangat para peserta (bagi } \\
\text { yang belum) untuk dapat } \\
\text { membangun unit usaha? }\end{array}$ & $\begin{array}{l}\text { Dilakukan penjelasan mengenai keutamaan } \\
\text { wirausaha, kunci kesuksesan dan memulai } \\
\text { usaha/bisnis } \\
\begin{array}{c}\text { - tanya jawab dan contoh } \\
\text { kasus }\end{array}\end{array}$ \\
\hline $\begin{array}{l}\text { Bagaimana meningkatkan } \\
\text { kemampuan dalam pengelolaan } \\
\text { atau manajemen unit usaha? }\end{array}$ & $\begin{array}{l}\text { Dilakukan pelatihan mengenai } \\
\text { pengololaan/manegemen bisnis. }\end{array}$ \\
\hline $\begin{array}{l}\text { Bagaimana cara memulai } \\
\text { melaksanakan strategi online } \\
\text { marketing untuk meningkatkan } \\
\text { penjualan? }\end{array}$ & $\begin{array}{l}\text { Dilakukan penjelasan mengenai bagaimana } \\
\text { memulai menjalankan strategi online } \\
\text { marketing untuk meningkatkan penjualan }\end{array}$ \\
\hline
\end{tabular}

\section{METODE}

Metode pelaksanaan kegiatan pelatihan ini adalah dengan cara memberikan pemaparan langsung kepada para peserta. Namun karena kondisi pandemic Covid-19, pelatihan dilakukan secara daring melalui aplikasi zoom. Berikut adalah tahapan-tahapan yang dilakukan dalam mewujudkan pelatihan ini.

a. Tahap Persiapan 
Berikut merupakan tahapan persiapan yang dilakukan dari awal hingga kegiatan pengabdian kepada masyarakat ini selesai dilakukan.

\section{Survey}

Tahap ini merupakan tahap paling awal yang dilakukan. Survey dilakukan dengan cara online yakni dengan mengisi google foam. Survey dilakukan terhadap para mahasiswa dan para pelaku usaha kecil dan UMKM mengenai tema apa yang cocok yang akan diankat menjadi tema pengabdian kepada masyarakat. Pertanyaan yang dilontarkan sangat sederhana yaitu para responden diminta memilih tema yang paling sesuai diantara ketiga tema yang ditawarkan. Tema yang ditawarkan adalah strategi online marketing, mengatur keuangan usaha, dan kreativitas dalam kewirausahaan. Dari 98 responden, $80 \%$ memilih tema strategi online marketing.

2. Pemantapan dan penetuan sasaran

Tahap ini dilakukan dengan cara memantapkan rencana pelatihan dengan internal tim. Dalam tahapan ini dibuatkan rencana detail terkait pelaksanaan kegiatan mulai dari pendaftaran sampai dengan akhir acara. Disamping itu pula ditetapkan target sasaran peserta yang akan mengikuti pelatihan tersebut. Berikut adalah rencana detail pelaksanaan pelatihan tersebut.

Tebel 2. Rencana pelaksanaan pelatihan

\begin{tabular}{|l|l|l|l|}
\hline No & Aktivitas & Waktu & PIC \\
\hline 1 & Penyebaran undangan & $\begin{array}{l}1-30 \text { November } \\
2020\end{array}$ & Mahasiswa \\
& & $\begin{array}{l}1-30 \text { November } \\
2020\end{array}$ & Mahasiswa \\
\hline 2 & Pendaftaran peserta & $1-4$ Desember & Mahasiswa \\
\hline 3 & Konfirmasi kehadiran & 2020 & \\
\hline 4 & Pelaksanaan & 5 Desember 2020 & Dosen \\
\hline 5 & Survey (feedback) & $5-6$ Desember & Mahasiswa \\
& & 2020 & \\
\hline
\end{tabular}

Kegiatan pertama adalah penyebaran undangan secara daring melalui grup-grup wa dan social media yang lain. Setelah itu para peserta mendaftar melalui g foam yang 
telah disediakan. Setelah mendekati acara para peserta yang telah mendaftar melakukan konfirmasi kehadiran dalam kegiatan ini. Peserta yang hadir dalam kegiatan ini adalah 198 orang yang terdiri dari mahasiswa dan masyarakat umum yang berminat dengan online marketing.

3. Penyusunan bahan/materi

Tahap ini meliputi penyusunan module dan presentasi power point yang akan disampaikan. Modul disusun dengan bahasa yang mudah agar dapat difahami. Penyusunan modul dilakukan selama dua hari dengan mengambil bahan-bahan referensi dari buku dan internet.

4. Persiapan peralatan dan alat peraga

Tahap ini memastikan bahwa peralatan pendukung seperti Laptop, jaringan internet, software zoom, dan lain-lain.

b. Tahap Pelaksanaan kegiatan

Pelaksanaan kegiatan pelatihan ini sesuai dengan jadwal yang telah ditentukan sebelumnya yakni tanggal 5 Desember 2020, adapun rincian detail mengenai pelaksanaan kegiatan ini adalah sebagai berikut:

1. Jumlah peserta pelatihan

Peserta yang mendaftar melalui google foam dan melakukan konfirmasi kehadiran sebanyak 215 orang, akan tetapi pada saat acara berlangsung terlihat pada aplikasi zoom sebanyak 198 orang. Dengan demikian ada penurunan peserta dari pendaftaran sebanyak 17 orang. Hal ini mungkin terjadi karena berbagai alasan diantaranya sakit, bekerja dan hal lain yang tidak dapat diduga sebelumnya.

2. Background peserta

Latar belakang peserta secara garis besar adalah para mahasiswa (mayoritas) dan para pelaku usaha. Beberapa dari mahasiswa juga ada yang telah mempunyai unit usaha sendiri di berbagai bidang. Berikut adalah komposisi dari 198 peserta. 


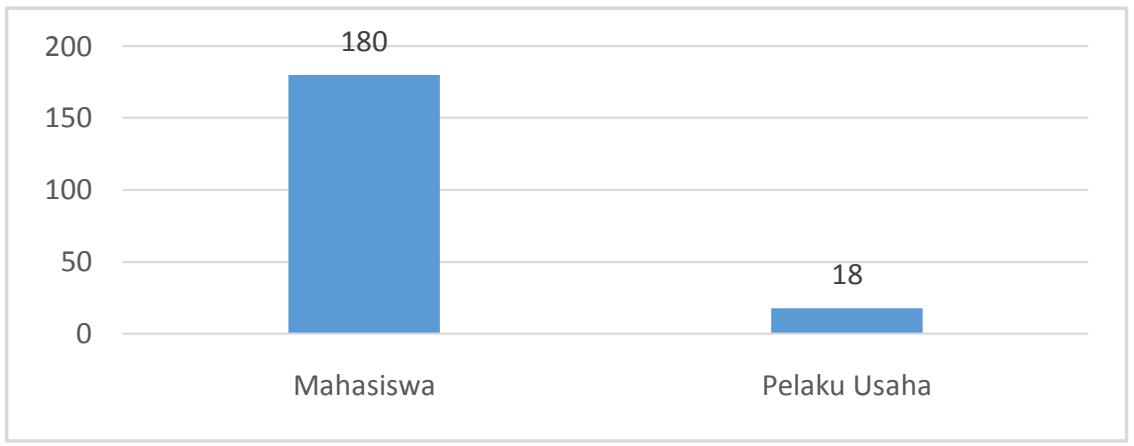

Gambar 1. Grafik komposisi peserta pelatihan

3. Tempat pelaksanaan

Dikarenakan kondisi masih pandemic Covid-19, pelaksanaan kegiatan ini dilakukan dengan bantuan platform zoom dengan ID 4285283159 dan password TIUBP.

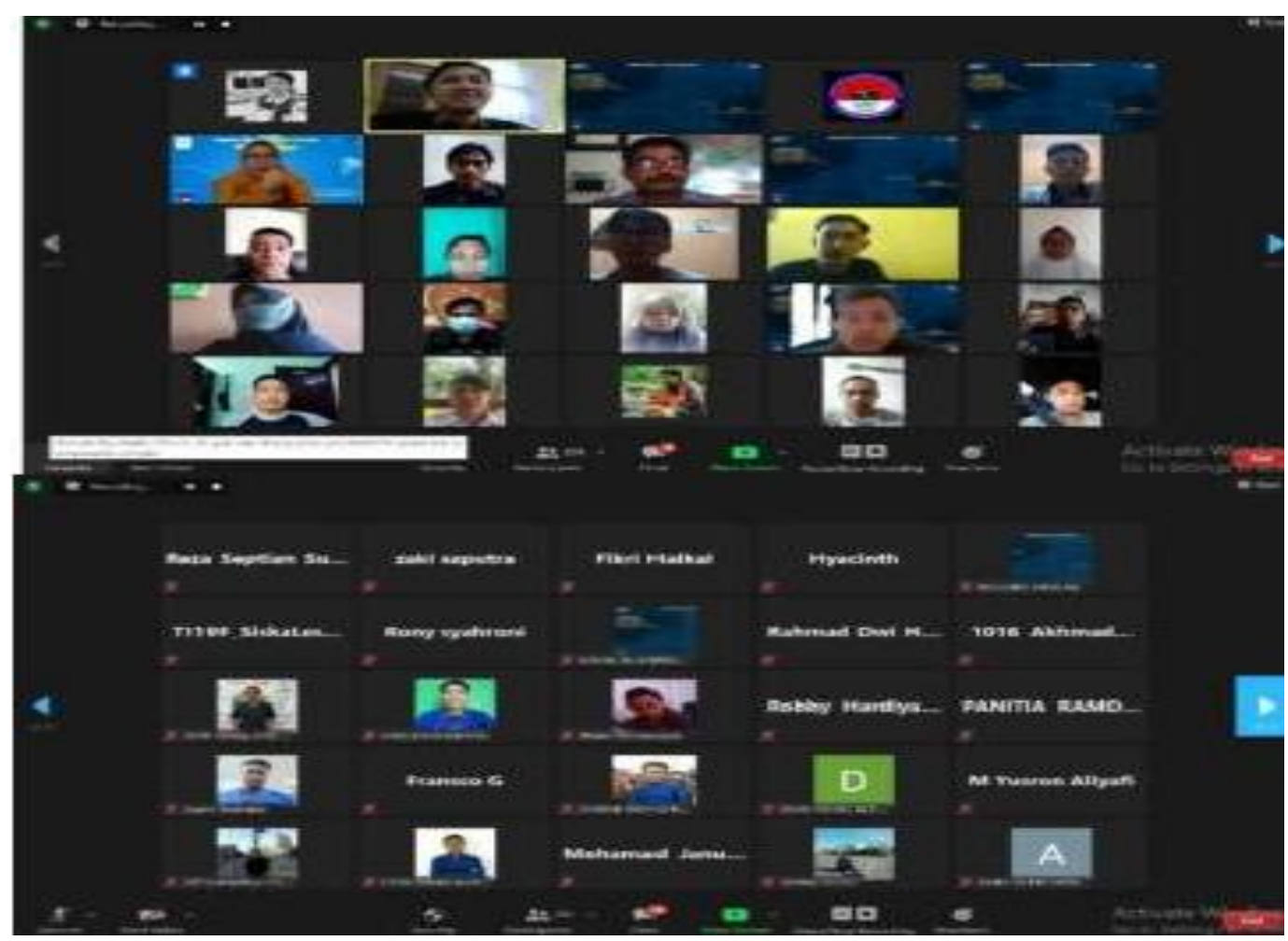

Gambar 2. Pelaksanaan kegiatan pelatihan

4. Rundown acara

Rundown acara dilalui satu persatu dengan lancar. Berikut adalah rundown acara yang dibuat sangat dan sederhana :

\begin{tabular}{|l|l|l|l|}
\hline No & Kegiatan & Pukul & PIC \\
\hline 1 & Pembukaan & $09.00-09.10$ & MC \\
\hline 2 & Menyanyikan lagu Indonesia Raya & $09.10-09.20$ & MC \\
\hline
\end{tabular}




\begin{tabular}{|l|l|l|l|}
\hline 3 & Sambutan Koor. Prodi & $09.20-09.30$ & Koor. Prodi \\
\hline 4 & Penyampaian materi pelatihan & $09.30-12.00$ & Tim dosen \\
\hline 5 & Doa Penutup & $12.00-12.10$ & MC \\
\hline
\end{tabular}

\section{HASIL DAN PEMBAHASAN}

Sebagai seorang entrepreneur dengan kondisi pandemic Covid-19 ini, harus berupaya mencari ide kreatif agar usaha yang dijalankan dapat terus berjalan. Salah satu improvement yang dapat dilakukan adalah mengubah strategi pemasaran dari konvensional (offline) menjadi online atau yang sering disebut online/internet marketing. Menurut Mohammed (2003), internet marketing adalah proses dalam membangun dan mempertahankan customer relationship melalui aktivitas online yang merupakan pertukaran ide, produk, jasa yang dapat memenuhi kepuasan pelanggan. Menurut Dianawati (2007) Pemasaran online adalah kegiatan komunikasi pemasaran dengan menggunakan media internet. Dari definisi di atas dapat disimpulkan bahwa internet marketing atau disebut juga online marketing adalah kegiatan marketing yang dilaksanakan secara online dalam jaringan internet. Kegiatan marketing dimaksud diantaranya promosi, transaksi, dan komunikasi dengan pelanggan. Beberapa bentuk online marketing diantaranya adalah social media marketing, penggunaan website toko, dan marketplace seperti Tokopedia, Shopee, Lazada, JDID, dan lain-lain. Daya jangkau online marketing tentunya jauh lebih banyak dari pada offline. Jika offline hanya mencakup daerah sekitar tempat took berada saja, maka online daya jangkaunya adalah seluruh warga dunia bukan hanya orang di Indonesia.

Bagi Sebagian orang melakukan strategi online marketing adalah mudah, namun sebagian besar menganggap strategi ini merupakan hal yang sulit untuk dilaksanakan. Sebagian dari mereka menganggap strategi online marketing membutuhkan kemampuan teknologi informasi yang tinggi. Padahal sebetulnya online marketing dapat dimulai dengan memanfaatkan social media yang dimiliki. Sebagian besar para peserta telah memiliki akun social media seperti Facebook, Instagram, Twitter, dan lain-lain, namun mayoritas belum memanfaatkan social media tersebut untuk mempromosikan jualannya. Beberapa alasan yang diungkapkan adalah malu, tidak punya banyak waktu untuk posting, tidak tahu caranya, dan takut tidak laku. Berikut merupakan hasil survey sederhana mengenai strategi online marketing yang dilaksanakan pada saat pelatihan terhadap 198 orang peserta. 

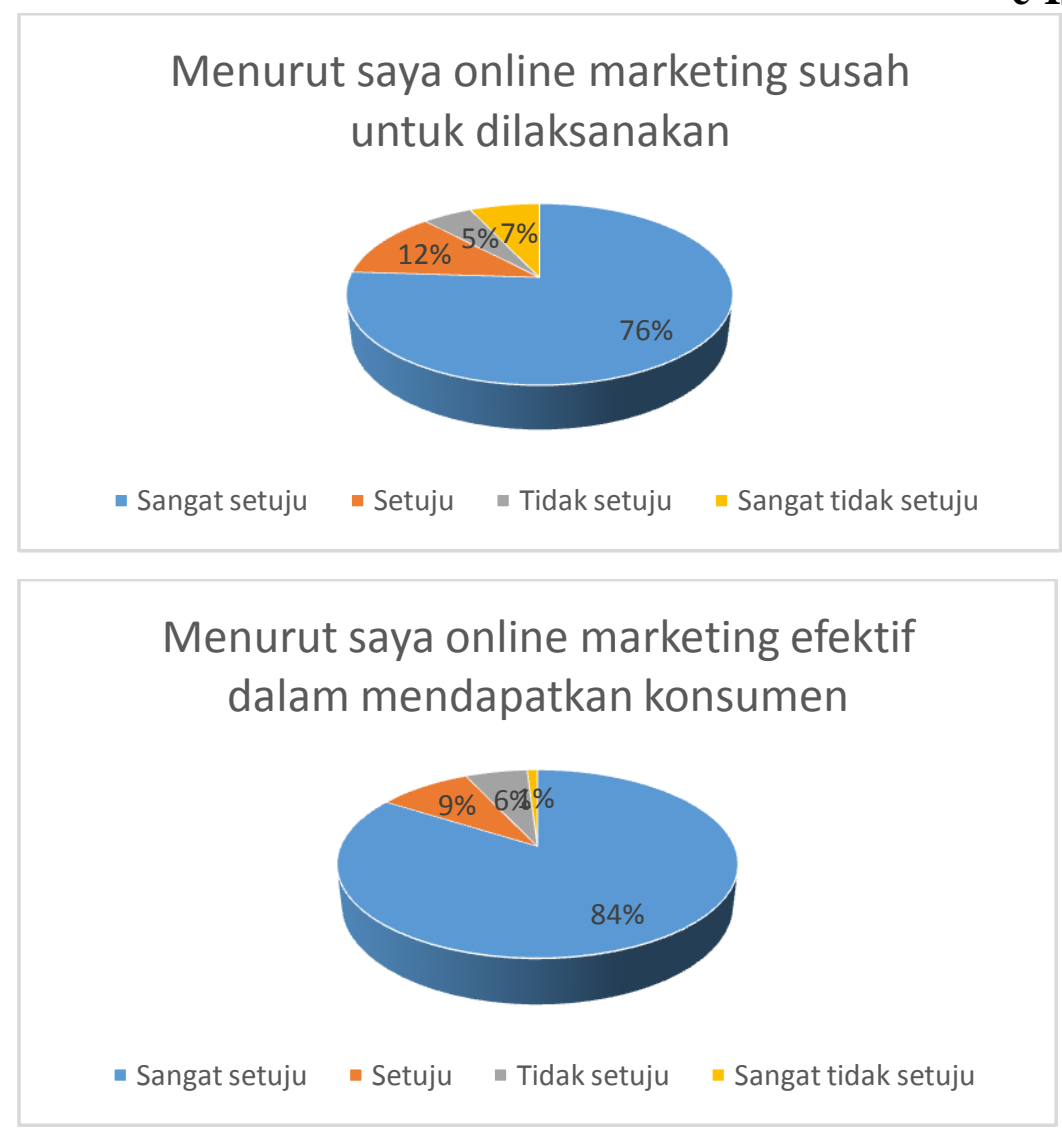

Gambar 3. Sebagian hasil survey terhadap peserta

Survey di atas menunjukkan bahwa Sebagian besar, sebanyak 76\% sangat setuju dan 12\% setuju masih beranggapan bahwa strategi online marketing merupakan hal yang susah/sulit dilaksanakan. Akan tetapi menariknya adalah meski mereka beranggapan sulit, tetapi mayoritas dari mereka yaitu $84 \%$ sangat setuju dan $9 \%$ setuju, menyadari bahwa online marketing efektif dalam mendapatkan konsumen terlebih dimasa pandemic Covid-19 seperti sekarang ini. Dengan demikian, gap tersebut sebetulnya adalah berupa ketidaktahuan mereka akan bagaimana memulai strategi online marketing sehingga menganggap bahwa online marketing sulit dilaksanakan. Oleh karena itu, untuk meminimalisir gap ataupun permasalahan tersebut, pelatihan ini sangat relevan sekali untuk dapat dilaksanakan.

Pelaksanaan kegiatan pada tanggal 5 Desember 2020 ini berjalan dengan lancar tanpa ada kendala yang berarti. Antusiasiasme para peserta dapat dilihat ketika pelaksanaan acara. Pada saat palaksanaan banyak peserta yang mengaktifkan kameranya dan terlihat begitu serius memperhatikan materi yang disampaikan. Antusiasme juga dapat dilihat dari banyaknya pertanyaan yang dilontarkan oleh peserta. Salah satu pertanyaan dari peserta adalah peralatan apa saja yang diperlukan dalam menjalankan online marketing. Pertanyaan tersebut dijawab oleh narasumber, peralatan minimal yang diperlukan adalah smartphone bisa android ataupun 
Afif Hakim, Nana Rahdiana, Annisa Indah Pratiwi

Vol. 3 No 1, Februari 2021

ISSN 2657-0203

e-ISSN 2686-0244

yang lainnya, idealnya adalah mempunyai juga laptop/komputer karena beberapa viewdapat dimunculkan dengan baik pada layer komputer dibandingkan pada layar smartphone. Setelah acara selesai ditanyakan bagaimana perasaan mereka mengikuti kegiatan ini, rata-rata menjawab kegiatan ini mempunyai banyak sekali manfaat yaitu ilmu marketing yang dapat dipraktekkan untuk meningkatkan penjualan. Berikut hasil survey feedback para peserta mengenai kegiatan pelatihan ini.

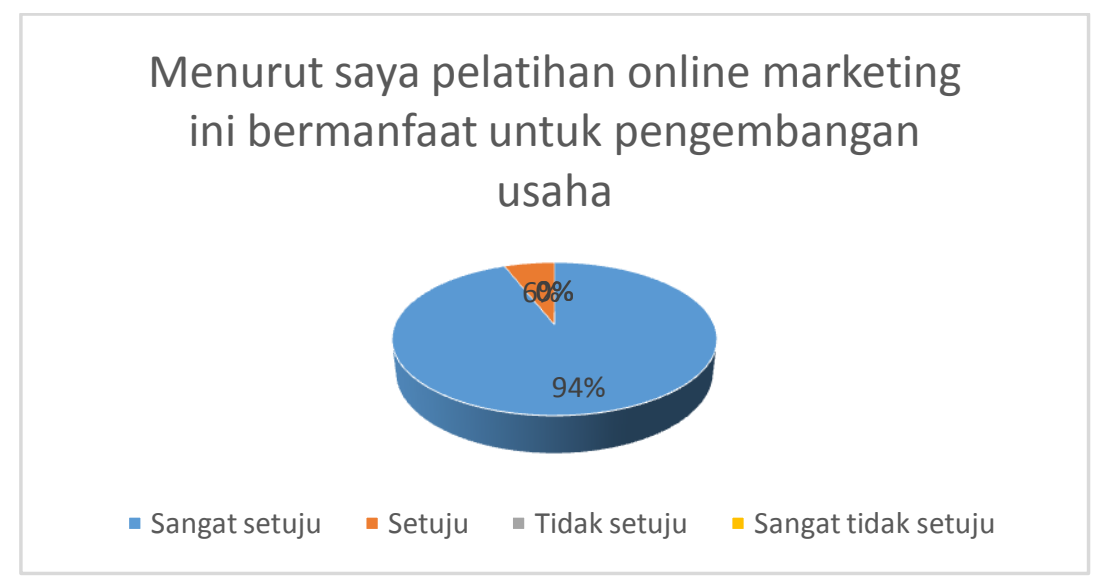

Gambar 4. Hasil survey feedback

Dari hasil survey di atas menunjukkan bahwa semua peserta dengan komposisi $94 \%$ sangat setuju dan 6\% setuju, berpendapat bahwa pelatihan ini memberikan manfaat untuk pengembangan usaha.

\section{KESIMPULAN DAN SARAN}

Kesimpulan dan saran yang dapat diambil dari kegiatan pelatihan strategi online marketing ini adalah :

1. Banyak para peserta yang beranggapan bahwa strategi online marketing sulit untuk dilaksanakan pada hal mereka menyadari bahwa strategi online marketing efektif untuk dilaksanakan terutama di saat-saat pandemic covid-19 ini sehingga pelatihan semacam ini penting untuk dilaksanakan untuk menghilangkan gap berupa ketidaktahuan para peserta.

2. Pelatihan berjalan dengan lancar dan para peserta terlihat antusias dalam melaksanakan pelatihan ini terbukti dari banyaknya pertanyaan yang dilontarkan dan hasil survey feedback menyatakan bahwa 100\% mereka setuju pelatihan membawa manfaat untuk pengembangan usaha.

3. Untuk kegiatan berikutnya, dapat dilakukan pelatihan kembali mengenai online marketing namun langsung detail sampai dengan bagaimana menginputkan barang 
Afif Hakim, Nana Rahdiana, Annisa Indah Pratiwi Vol. 3 No 1, Februari 2021

ISSN 2657-0203 e-ISSN 2686-0244

pada market place seperti shopee, tokopedia, lazada, dan lain-lain.

\section{DAFTAR PUSTAKA}

Bps.go.id diakses pada 10 Desember 2020

Dianawati, Ajen. (2007). 6 Rahasia Sukses Menjadi Jutawan Internet, cet. I. Jakarta: Mediakita

Mohammed, Rafi A., et al. 2003. Internet Marketing Building Advantage. In A Nerworked Economy, Second Edition. New York: McGraw-Hill/Irwin. 